\title{
FAKTOR-FAKTOR YANG MEMPENGARUHI PRODUKTIVITAS KARYAWAN PADA CV. GRANADA
}

\author{
Subarjo \\ Universitas Mercu Buana Yogyakarta \\ Subarjo91@yahoo.com
}

\begin{abstract}
This research is a descriptive study that aims to determine the effect either partially or simultaneously between the level of education, age of work, motivation and work experience on employee productivity. This research was conducted at CV Granada where the overall number of employees 50 people used as a sample in this study. Validity and reliability, Normality Test and Classical Assumption Test carried out on the research instrument before the data were tested using multiple linear regression analysis. Multiple Linear Regression Test results showed that partially working age, motivation, and work experience positive and significant impact on employee productivity, while the education level is not proven effect. Simultaneously between level of education, age of work, motivation and work experience have a significant effect on employee productivity.
\end{abstract}

Keywords: education, motivation, working age, work experience, productivity

\section{PENDAHULUAN}

Sejalan dengan perkembangan ekonomi dewasa ini, dunia usaha dengan sendirinya akan mengalami pertumbuhan dan mendorong berkembang ke arah yang lebih baik serta mampu bersaing. Banyak perusahaan yang mengalami kebangkrutan akibat tidak mampu bersaing dengan perusahaan lain. Apalagi dengan adanya pasar bebas, persaingan dalam dunia usaha kian terasa. Sehingga agar mampu bersaing, perusahaan harus melakukan perbaikan-perbaikan dalam berbagai hal. Perbaikan yang paling utama adalah dibidang sumber daya manusia, karena sumber daya manusia merupakan faktor utama dalam kegiatan setiap operasional perusahaan.

Seiring dengan berkembangnya dunia usaha, perusahaan-perusahaan berusaha meningkatkan kualitas tenaga kerja sebagai penggerak perusahaan. Karena pembangunan sumbar daya manusia atau tenaga kerja merupakan salah satu upaya untuk peningkatan mutu dan kemampuan usaha yang sesuai dengan kebutuhan dan harapan dunia usaha dengan harapan output produktivitas yang tinggi.

Produktivitas sumber daya manusia atau tenaga kerja merupakan hal yang sangat penting, karena produktivitas tenaga kerja memiliki peran besar dalam menentukan sukses tidaknya suatu usaha. Oleh karena itu produktivitas harus menjadi bagian yang tidak boleh dilupakan dalam menyusun strategi bisnis, yang mencakup bidang produksi, pemasaran, keuangan dan bidangbidang lainnya. Produktivitas tenaga kerja merupakan salah satu faktor yang mempunyai peranan besar dalam menentukan sukses tidaknya dalam kegiatan usaha. Dengan meningkatnya produktivitas tenagakerjaini secaratidaklangsung akan memberikan kepuasan kerja kepada para pekerja, selain itu juga akan mendorong motivasi para pekerja untuk meningkatkan kinerja menjadi lebih baik lagi.

Adapun permasalahan yang tidak kalah penting dalam manajemen sumber daya 
manusia adalah untuk mengetahui faktorfaktor yang mempengaruhi produktivitas kerja karyawannya. Yang mempengaruhi produktivitas kerja karyawan menjadi masalah yang rumit dan penting dikarenakan besarnya manfaat yang didapat dari yang mempengaruhi produktivitas kerja karyawan bagi individu, industri, dan masyarakat. Bagi individu, yang mempengaruhi produktivitas kerja karyawan memungkinkan mereka untuk lebih berusaha meningkatkan kebahagiaan hidup mereka. Bagi industri, yang mempengaruhi produktivitas kerja karyawan digunakan sebagai pemacu peningkatan produksi dan pengurangan biaya melalui perbaikan sikap dan tingkah laku karyawan.

Setiap organisasi pada dasarnya akan memiliki kebijakan yang berbeda-beda terhadap sumber daya manusia yang dimilikinya guna mencapai produktivitas kerja karyawan. Dalam pencapaian produktivitas kerja karyawan terdapat banyak faktor yang mempengaruhi antara lain adalah adanya tingkat pendidikan, motivasi, usia dan pengalaman kerja karyawan bertambah. Keempat yang mempengaruhi produktivitas kerja karyawan tersebut diharapkan mampu memberikan jalan bagi karyawan guna mencapai produktivitas kerja yang lebih baik lagi.

Permasalahan ini juga dialami dan muncul pada CV Granada yang usahanya bergerak dibidang konveksi. Usaha yang dilakukan perusahaan dalam perebutan pasar adalah dengan meningkatkan kualitas pelayanan kepada pelanggan dan melakukan perubahan dan sistem agar lebih fleksibel dalam menghadapi persaingan. Upaya tersebut di atas diwujudkan dalam tujuan perusahaan yaitu untuk meningkatkan pendapatan usaha yang ditempuh dengan cara mengoptimalkan produktivitas kerja karyawan. Pentingnya pencapaian produktivitas kerja hal ini dikarenakan produktivitas kerja pada dasarnya suatu sikap yang selalu mempunyai pandangan bahwa mutu kehidupan hari ini harus lebih baik dari hari kemarin.
Dari uraian di atas terlihat bahwa tujuan dari studi ini adalah untuk mengetahui dan menganalisis factor-faktor yang mempengaruhi produktivitas kerja karyawan CV Granada. Selain itu juga perlu diketahui factor yang paling dominan mempengaruhi produktivitas kerja karyawan.

\section{REVIEW LITERATUR DAN HIPOTESIS}

\section{Produktifitas Kerja}

Setiap perusahaan selalu berusaha agar karyawan bisa berprestasi dalam bentuk memberikan produktivitas kerja yang maksimal. Produktivitas kerja karyawan bagi suatu perusahaan sangatlah penting sebagai alat pengukur keberhasilan dalam menjalankan usaha. Karena semakin tinggi produktivitas kerja karyawan dalam perusahaan, berarti laba perusahaan dan produktivitas akan meningkat.

Tjutju Yuniarsih \& Suwatno (2009:156) mengemukakan bahwa produktivitas kerja dapat diartikan sebagai hasil kongkrit (produk) yang dihasilkan oleh individu atau kelompok, selama satuan waktu tertentu dalam suatu proses kerja. Dalam hal ini, semakin tinggi produk yang dihasilkan dalam waktu yang semakin singkat dapat dikatakan bahwa tingkat produktivitasnya mempunyai nilai yang tinggi begitupun sebaliknya. Nawawi dalam Tjutju Yuniarsih (2009:157) mengemukakan bahwa produktivitas kerja merupakan perbandingan antara hasil yang diperoleh (output) dengan jumlah sumber daya yang dipergunakan sebagai masukan (input). Adapun Nanang Fattah dalam Tjutju Yuniarsih (2009:157) menyimpulkan bahwa dalam konsep produktivitas berkembang dari pengertian teknis sampai kepada pengertian perilaku. Produktivitas dalam arti teknis mengacu pada derajat keefektifan dan efisiensi dalam penggunaan berbagai sumber daya, sedangkan dalam pengertian perilaku, produktivitas merupakan sikap mental yang senantiasa berusaha untuk terus berkembang. 
Berdasarkan uraian tersebut dapat dipahami produktivitas dapat dimaknai sebagai nilai output dalam interaksi dan interelasinya dengan kesatuan nilai-nilai input. Produktivitas kerja karyawan biasanya dinyatakan sebagai imbangan hasil rata-rata yang dicapai oleh tenaga kerja, selama jam kerja yang tersedia dalam proses produksi. Sehubungan dengah hal tersebut, konsep produktivitas pada dasarnya mencakup sikap mental dan perilaku yang berorientasi pada perbaikan berkelanjutan (continuous improvement), dan mempunyai pandangan bahwa kinerja hari ini harus lebih baik dari hari kemarin, dan kinerja hari esok mesti lebih baik dari prestasi hari ini.

Konsep produktivitas pada dasarnya dapat dilihat dari dua dimensi, yaitu dimensi individu dan dimensi organisasi. Pengkajian masalah produktivitas dari dimensi individu tidak lain melihat produktivitas terutama dalam hubungannya dengan karakteristik-karakteristik kepribadian individu. Dalam konteks ini esensi pengertian produktivitas adalah sikap mental yang selalu mempunyai pandangan bahwa mutu kehidupan hari ini harus lebih baik dari hari kemarin, dan hari esok harus lebih baik dari hari ini (Kusnendi, 2003:8.4).

Dalam upaya meningkatkan produktivitas kerja karyawan di suatu perusahaan perlu memperhatikan faktor-faktor yang mempengaruhi produktivitas kerja karyawan tersebut. Banyak faktor yang dapat mempengaruhi produktivitas kerja karyawan baik yang berhubungan dengan tenaga kerja itu sendiri maupun faktor-faktor yang berhubungan dengan lingkungan perusahaan dan kebijakan pemerintah secara keseluruhan.

Menurut Pandji Anoraga (2005: 56-60). Ada 10 faktor yang sangat diinginkan oleh para karyawan untuk meningkatkan produktivitas kerja karyawan, yaitu: (1) pekerjaan yang menarik, (2) upah yang baik, (3) keamanan dan perlindungan dalam pekerjaan, (4) etos kerja dan (5) lingkungan atau sarana kerja yang baik, (6) promosi dan perkembangan diri mereka sejalan dengan perkembangan perusahaan, (7) merasa terlibat dalam kegiatan-kegiatan organisasi, (8) pengertian dan simpati atas persoalan-persoalan pribadi, (9) kesetiaan pimpinan pada diri sipekerja, (10) Disiplin kerja yang keras.

Menurut Payaman J. Simanjutak (2007: 30) faktor yang mempengaruhi produktivitas kerja karyawan perusahaan dapat digolongkan pada dua kelompok, yaitu: pertama, yang menyangkut kualitas dan kemampuan fisik karyawan yang meliputi: tingkat pendidikan, latihan, motivasi kerja, etos kerja, mental dan kemampuan fisik karyawan. Kedua, berupa sarana pendukung yang meliputi: a). Lingkungan kerja (produksi, sarana dan peralatan produksi, tingkat keselamatan, dan kesejahteraan kerja). b) Kesejahteraan karyawan (Manajemen dan hubungan industry).

Dari berbagai pendapat di atas dapat disimpulkan kondisi utama karyawan yang semakin penting dan menentukan tingkat produktivitas karyawan yaitu pendidikan dan pelatihan, motivasi, usia ,disiplin, ketrampilan, tingkat penghasilan, lingkungan dan pengalaman kerja, serta penguasaan peralatan. Dengan harapan agar karyawan semakin gairah dan mempunyai semangat dalam bekerja dan akhirnya dapat mempertinggi mutu pekerjaan, meningkatkan produksi dan produktivitas kerja.

Namun demikian penelitian ini hanya membatasi empat faktor yang diduga dapat mempengaruhi produktivitas kerja karyawan, yaitu tingkat pendidikan, motivasi, usia dan pengalaman kerja. Adapun alur kerangka pikirnya dapat digambarkan sebagai berikut:

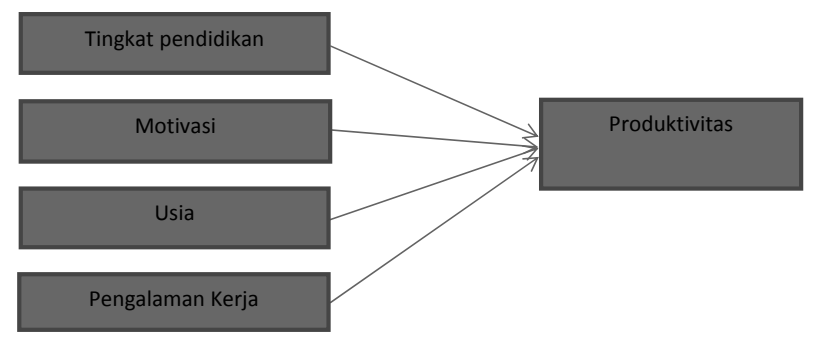

Gambar 1 Kerangka Pikir Penelitian 


\section{Tingkat Pendidikan Dan Produktivitas}

Bekal tingkat pendidikan yang cukup dan memadai diharapkan akan dapat memperbesar produktivitas kerja karyawan. Prestasi akademis yang telah dicapai oleh karyawan yang bersangkutan selama mengikuti jenjang pendidikan harus mendapatkan pertimbangan. Dengan mempertimbangkan faktor prestasi akademis, maka dapat ditetapkan dimana karyawan yang bersangkutan akan ditempatkan sesuai dengan prestasi akademisnya.

Pendidikan yang minim mengakibatkan kurangnya pengetahuan dalam memanfaatkan sumber sumber alam yang tersedia. Hal ini berakibatkan pada setiap usaha usaha penduduk yang hanya mampu menghasilkan pendapatan yang rendah. Rendahnya mutu SDM (pengetahuan dan keterampilan karyawan) karena kurangnya pendidikan dan pelatihan yang mereka peroleh. Sehingga dari hal tersebut dapat disusun hipetisis sebagai berikut:

$\mathrm{H}_{1}$ : Diduga terdapat pengaruh positif dan signifikan tingkat pendidikan terhadap produktivitas karyawan

\section{Motivasi Dan Produktivitas}

Menurut T. Hani Handoko (2003 : 252 ), motivasi adalah keadaan dalam pribadi seseorang yang mendorong keinginan individu untuk melakukan kegiatan-kegiatan tertentu guna mencapai tujuan. Apabila seseorang sudah terdorong atau termotivasi, maka pekerjaan yang dilakukan hasilnya akan memuaskan. Memotivasi merupakan kegiatan yang mengakibatkan, menyalurkan dan memelihara perilaku manusia atau bisa dikatakan sebagai suatu proses untuk mencoba mempengaruhi seseorang agar melakukan sesuatu yang kita inginkan atau dengan kata lain dorongan dari luar terhadap seseorang agar mau melaksanakan sesuatu.

Motivasi dalam diri karyawan sangat diperlukan untuk lebih meningkatkan produktivitas karyawan itu sendiri. Dengan adanya motivasi, seorang karyawan akan terdorong untuk melakukan kerja yang lebih baik dari pada sebelumnya, dan hal ini akan meningkatkan produktivitas mereka. Maka dapat terlihat adanya suatu pengaruh antara motivasi karyawan terhadap produktivitasnya. Selanjutnya hubungan antara motivasi dan Produktivitas dapat di hipotesiskan sebagai berikut:

$\mathrm{H}_{2}$ : Diduga terdapat pengaruh positif dan signifikan motivasi terhadap produktivitas karyawan

\section{Usia Karyawan Dan Produktivitas}

Dalam rangka menempatkan karyawan, faktor usia pada diri karyawan yang lulus dalam seleksi perlu mendapatkan pertimbangan. Hal tersebut dimaksudkan untuk menghindari rendahnya produktivitas yang dihasilkan oleh karyawan yang bersangkutan. Karyawan berusia lanjut berumur 65 tahun keatas, biasanya fanatik terhadap tradisi dan sulit untuk diberikan pengertian yang dapat mengubah cara berpikir, cara kerja, dan cara hidupnya. Karyawan lanjut usia bersikap apatis terhadap adanya teknologi baru.. Usia tenaga kerja yang produktif berumur 16-64 tahun, sedangkan pada usia 65 keatas sudah dikatakan usia lanjut (Van den Ban dan Hakwiks, 1999). Oleh karena itu disusunlah hipotesis sebagai berikut:

$\mathrm{H}_{3}$ : Diduga terdapat pengaruh positif dan signifikan usia karyawan terhadap produktivitas karyawan.

\section{Pengalaman Kerja Dan Produktivitas}

Pengalaman dalam semua kegiatan sangat diperlukan, karena experience is the best teacher, pengalaman guru yang terbaik. Maksud dari hal tersebut adalah bahwa seseorang belajar dari pengalaman yang pernah dialaminya. Menurut Kamus Bahasa Indonesia (Depdiknas, 2005: 26), "pengalaman dapat diartikan sebagai yang pernah dialami (dijalani, dirasa, ditanggung, dsb)".

Elaine B Johnson (2007: 228) menyatakan bahwa "pengalaman memunculkan potensi 
seseorang. Potensi penuh akan muncul bertahap seiring berjalannya waktu sebagai tanggapan terhadap bermacam-macam pengalaman". Jadi sesungguhnya yang penting diperhatikan dalam hubungan tersebut adalah kemampuan seseorang untuk belajar dari pengalamannya, baik pegalaman manis maupun pahit. Maka pada hakikatnya pengalaman adalah pemahaman terhadap sesuatu yang dihayati dan dengan penghayatan serta mengalami sesuatu tersebut diperoleh pengalaman, ketrampilan ataupun nilai yang menyatu pada potensi diri.Orang yang berpengalaman dalam bekerja memiliki kemampuan kerja yang lebih baik dari orang yang baru saja memasuki dunia kerja, karena orang tersebut telah belajar dari kegiatankegiatan dan permasalahan yang timbul dalam kerjanya. Dengan adanya pengalaman kerja maka telah terjadi proses penambahan ilmu pengetahuan dan ketrampilan serta sikap pada diri seseorang, sehingga dapat menunjang dalam mengembangkan diri dengan perubahan yang ada.Dengan pengalaman yang didapat seseorang akan lebih cakap dan terampil serta mampu melaksanakan tugas pekerjaannya.

Pengalaman kerja mempunyai pengaruh terhadap banyaknya produksi, besar kecilnya dan efisiensi yang dapat dilihat dari hasil produksi tenaga kerja yang diarahkan. Dalam pengertian lain, pengalaman kerja juga dapat diperoleh dengan melewati masa kerja yang telah dilakui disuatu tempat kerja. Pengalaman kerja seseorang dalam suatu pekerjaan yang dimanifestasikan dalam jumlah masa kerja akan meningkatkan kemampuan dan kecakapan kerja seseorang sehingga hasil kerja akan semakin meningkat.Pengalaman kerja tidak hanya menyangkut jumlah masa kerja, tetapi lebih dari juga memperhitungkan jenis pekerjaan yang pernah atau sering dihadapi. Sejalan dengan bertambahnya pekerjaan, maka akan semakin bertambah pula pengatahuan dan ketrampilan seseorang dalam bekerja. Hal tersebut dapat dipahami karena terlatih dan sering mengulang suatu pekerjaan sehingga kecakapan dan ketrampilan semakin dikuasai secara mudah, tetapi sebelumnya tanpa latihan, pengalamanpengalaman yang pernah dimiliki akan menjadi berkurang bahkan terlupakan.

Atas dasar uraian di atas, maka hipotesis yang bias disusun adalah sebagai berikut:

$\mathrm{H}_{4}$ : Diduga terdapat pengaruh positif dan signifikan pengalaman kerja terhadap produktivitas karyawan

\section{METODE PENELITIAN}

Studi ini merupakan penelitian deskriptif dimana populasinya adalah seluruh karyawan CV Granada yang berjumlah 50 orang. Mengingat populasi kurang dari 100, maka semua karyawan diambil sebagai sampel, sehingga penelitiannya merupakan penelitian populasi/sensus.

\section{Pengukuran Dan Definisi Operasional Variabel}

Variabel dependen dalam penelitian ini adalah produktivitas, yaitu ukuran tingkat penggunaan sumber-sumber untuk mencapai sesuatu yang berhubungan dengan efektivitas dalam mencapai suatu misi atau prestasi yang diharapkan. Pengukuran variabel produktivitas karyawan menggunakan instrumen yang terdiri atas 3 pernyataan, disusun menggunakan skala likert 5 poin (sangat tidak setuju sampai dengan sangat setuju).

Variabel independen dalam penelitian ini sebanyak 4 variabel yaitu:

a. Tingkat Pendidikan, yaitu persepsi individu terhadap pekerjaan atas dasar pendidikan tertinggi.

b. Motivasi, yaitu persepsi individu terhadap keadaan dalam pribadi seseorang yang mendorong keinginan individu untuk melakukan kegiatan-kegiatan tertentu guna mencapai tujuan.

c. Usia, yaitu persepsi individu terhadap pekerjaan berdasar usia. 
d. Pengalaman Kerja, yaitu persepsi individu terhadap tingkat penguasaan pengetahuan serta ketrampilan seseorang dalam pekerjaannya yang dapat diukur dari masa kerja dan dari tingkat pengetahuan serta ketrampilan yang dimilikinya

Pengukuran keempat variabel tersebut menggunakan instrumen yang terdiri masingmasing atas 4 pernyataan, disusun menggunakan skala likert 5 poin (sangat tidak setuju sampai dengan sangat setuju)

\section{Metode Analisis Data}

Metode analisis data yang digunakan dalam penelitian ini adalah analisis regresi berganda. Analisis regresi berganda dalam penelitian ini digunakan untuk mengetahui faktor yang mempengaruhi produktivitas karyawan $\mathrm{CV}$ Granada.

Analisis Validitas dan Reliabilitas juga digunakan untuk menguji kuesioner yang akan diisi oleh responden. Hasil menunjukkan bahwa semua iten pernyataan yang ada dalam kuesioner sebanyak 19 item dinyatakan valid, dan ke empat variable dinyatakan reliable.

Berdasarkan hasil perhitungan Analisis Faktor terhadap ke lima variable (produktivitas, tingkat pendidikan, motivasi, usia, dan pengalaman kerja) diperoleh hasil sebagai berikut: rata-rata indikator produktivitas karyawan, tingkat pendidikan, motivasi kerja, usia, dan pengalaman kerja tidak menunjukkan penyimpangan data hal tersebut dikarenakan nilai rata-rata lebih besar dari standar deviasi .

\section{Tabel 1}

Statistik Deskriptif

\begin{tabular}{|l|r|r|r|r|r|}
\hline & $\mathrm{N}$ & Minimum & Maximum & Mean & $\begin{array}{c}\text { Std. } \\
\text { Deviation }\end{array}$ \\
\hline $\begin{array}{l}\text { Produktivitas } \\
\text { Karyawan }\end{array}$ & 50 & 2.50 & 3.75 & 2.9100 & .24620 \\
\hline Tingkat Pendidikan & 50 & 3.00 & 4.75 & 3.9150 & .33334 \\
\hline Motivasi Kerja & 50 & 3.00 & 4.75 & 3.9100 & .34251 \\
\hline Usia & 50 & 3.00 & 4.50 & 3.8300 & .35871 \\
\hline Pengalaman Kerja & 50 & 3.00 & 4.75 & 3.8750 & .39528 \\
\hline Valid N (listwise) & 50 & & & & \\
\hline
\end{tabular}

Sumber : Data olah SPSS 16.00
Berdasar hasil Uji Asumsi Klasik diperoleh hasil untuk uji Normalitas data yang digunakan dalam penelitian ini berdistribusi secara normal. Berdasar Uji Multikolinearitas model regresi tersebut tidak terdapat masalah multikolinearitas. Setelah dilakukan pengujian dengan menggunakan Rank Spearman didapatkan bahwa variabel independen tidak mempunyai korelasi dengan residualnya. Dengan tingkat sigifikansi masing-masing variabelnya lebih dari $5 \%$, sehingga dapat diambil kesimpulan bahwa tidak terdapat heteroskedastisitas.

\section{HASIL PENELITIAN DAN PEMBAHASAN}

\section{Hasil Penelitian}

Berdasar perhitungan Analisis Regresi Linear Berganda diperoleh hasil sebagai berikut:

\section{Tabel 2}

\section{Hasil Uji Regresi Linear Berganda}

\begin{tabular}{|c|c|c|c|c|c|c|}
\hline \multirow{2}{*}{\multicolumn{2}{|c|}{ Model }} & \multicolumn{2}{|c|}{$\begin{array}{c}\text { Unstandardized } \\
\text { Coefficients }\end{array}$} & \multirow{2}{*}{$\begin{array}{c}\text { Standardized } \\
\text { Coefficients } \\
\text { Beta } \\
\end{array}$} & \multirow[t]{2}{*}{$\mathrm{t}$} & \multirow[t]{2}{*}{ Sig. } \\
\hline & & $\mathrm{B}$ & Std. Error & & & \\
\hline \multirow{5}{*}{1} & (Constant) & 2.927 & .475 & & 6.162 & .000 \\
\hline & \begin{tabular}{|l|} 
Tingkat \\
Pendidikan
\end{tabular} & .086 & .096 & .151 & .895 & .375 \\
\hline & Motivasi Kerja & -.122 & .084 & .320 & 1.851 & .043 \\
\hline & \begin{tabular}{|l} 
Pengalaman \\
Kerja
\end{tabular} & .190 & .092 & .305 & 2.062 & .040 \\
\hline & Usia & -.159 & .127 & .332 & 1.757 & .047 \\
\hline
\end{tabular}

a. Dependent Variable: Produktivitas Karyawan

\section{Sumber : Data olah SPSS 16.00}

Pada tabel 2 di atas terlihat nilai t hitung untuk variabel tingkat pendidikan adalah 0.895 , sedangkan nilai t tabelnya adalah sebesar 1.750 $(\mathrm{df}=50-4-1=45)$. Selain itu, nilai signifikansinya didapat 0,375 . Sehingga didapat bahwa variabel tingkat pendidikan tidak berpengaruh terhadap produktivitas karyawan. Hal ini disebabkan nilai Thitung lebih kecil daripada t tabel. Nilai thitung $<$ t tabel $(0.895<1,750)$ dan nilai signifikansi lebih besar daripada taraf signifikansi $(\alpha) 0,05$ $(0,375>0,05)$, artinya tingkat pendidikan tidak berpengaruh positif dan signifikan terhadap 
produktivitas karyawan (Hipitesis 1 tidak terbukti).

Nilai t hitung untuk variabel motivasi kerja adalah 1.851 , sedangkan nilai $t$ tabelnya adalah sebesar $1.750(\mathrm{df}=50-4-1=45)$. Selain itu, nilai signifikansinya didapat 0,043 . Sehingga didapat bahwa variabel motivasi kerja berpengaruh terhadap produktivitas karyawan. Hal ini disebabkan nilai $\mathrm{T}$ hitung lebih besar daripada $t$ tabel. Nilai $t$ hitung $>t$ tabel $(1.851>$ $1,750)$ dan nilai signifikansi lebih besar daripada taraf signifikansi $(\alpha) 0,05(0,043<0,05)$, artinya motivasi kerja berpengaruh positif dan signifikan terhadap produktivitas karyawan (Hipotesis 2 terbukti).

Hipotesis 3 bisa dijawab dengan melihat nilai t hitung untuk variabel Pengalaman kerja adalah 2.062, sedangkan nilai t tabelnya adalah sebesar $1.750(\mathrm{df}=50-4-1=45)$. Selain itu, nilai signifikansinya didapat 0,040 . Sehingga didapat bahwa variabel pengalaman kerja berpengaruh terhadap produktivitas karyawan. Hal ini disebabkan nilai $\mathrm{T}$ hitung lebih besar daripada $\mathrm{t}$ tabel. Nilai $\mathrm{t}$ hitung $>\mathrm{t}$ tabel $(2.062>1,750)$ dan nilai signifikansi lebih besar daripada taraf signifikansi $(\alpha) 0,05(0,040<0,05)$, artinya pengalaman kerja berpengaruh positif dan signifikan terhadap produktivitas karyawan, yang berarti hipotesis 3 terbukti

Pada hipotesis 4 nilai $t$ hitung untuk variabel Usia Karyawan adalah 1.757 , sedangkan nilai $\mathrm{t}$ tabelnya adalah sebesar $1.750(\mathrm{df}=50-4$ $1=45$ ). Selain itu, nilai signifikansinya didapat 0,047 . Sehingga didapat bahwa variabel usia karyawan berpengaruh terhadap produktivitas karyawan. Hal ini disebabkan nilai $\mathrm{T}$ hitung lebih besar daripada $\mathrm{t}$ tabel. Nilai $\mathrm{t}$ hitung $>\mathrm{t}$ tabel $(1.757>1,750)$ dan nilai signifikansi lebih besar daripada taraf signifikansi $(\alpha) 0,05(0,047<$ $0,05)$, artinya usia karyawan berpengaruh positif dan signifikan terhadap produktivitas karyawan (hipotesis 4 terbukti).
Selanjutnya dihitung pula koefisien determinasi yang digunakan untuk mengetahui proporsi pengaruh variabel independen terhadap variabel dependen. Nilai $\mathrm{R}^{2}$ menunjukkan seberapa besar model regresi mampu menjelaskan variabilitas variabel tergantung atau menunjukkan proporsi pengaruh variabel independen terhadap variabel dependen. Adapun hasil perhitungan dapat dilihat pada tabel 3 sebagai berikut :

Tabel 3

Perhitungan Koefisien Determinasi Model Summary

\begin{tabular}{l|r|r|r|r|r|}
\hline Model & $\mathrm{R}$ & R Square & $\begin{array}{r}\text { Adjusted } \\
\text { R Square }\end{array}$ & $\begin{array}{r}\text { Std. Error of } \\
\text { the Estimate }\end{array}$ & Durbin-Watson \\
\hline 1 & $.671^{\mathrm{a}}$ & .638 & .761 & .23858 & 1.809 \\
\hline
\end{tabular}
a. Predictors: (Constant), Usia, Pengalaman Kerja, Motivasi Kerja,
Tingkat Pendidikan
b. Dependent Variable: Produktivitas Karyawan
Sumber:Data olah SPSS 16.00

Koefisien determinasi (Adjusted R Square) yang diperoleh adalah sebesar 0.761 atau $76.1 \%$, yang berarti angka $76.1 \%$ tersebut merupakan nilai persentase pengaruh variabel independen tingkat pendidikan, usia kerja, motivasi kerja dan pengalaman kerja terhadap produktivitas karyawan. Sedangkan sisanya sebesar $23.9 \%$ dijelaskan oleh variabel lain yang tidak diteliti.

\section{HASIL PENELITIAN DAN PEMBAHASAN}

Dari analisis hasil penelitian data diatas maka dapat dijelaskan bahwa : berdasarkan hasil penelitian dapat diketahui nilai uji , untuk variabel tingkat pendidikan adalah 0.895 , sedangkan nilai $\mathrm{t}$ tabelnya adalah sebesar $1.750(\mathrm{df}=50-4$ $1=45$ ). Selain itu, nilai signifikansinya didapat 0,375 . Sehingga dapat disimpulkan bahwa secara parsial tingkat pendidikan tidak berpengaruh terhadap produktivitas karyawan. Hal ini tidak didukung dengan penelitian terdahulu yang dilakukan oleh Pajar (2008) bahwa tingkat pendidikan berpengaruh terhadap produktivitas karyawan. Tingkat pendidikan tidak berpengaruh karena dari karyawan menilai tingkat pendidikan dianggap belum tentu menjamin bahwasanya dalam peningkatan produktivitas karyawan. 
Pada variabel motivasi kerja, nilai $\mathrm{t}$ hitung untuk variabel motivasi kerja adalah 1.851, sedangkan nilai t tabelnya adalah sebesar $1.750(\mathrm{df}=50-4-1=45)$. Selain itu, nilai signifikansinya didapat 0,043 . Sehingga dapat disimpulkan bahwa secara parsial motivasi kerja berpengaruh terhadap produktivitas karyawan. Hal ini didukung dengan penelitian terdahulu yang dilakukan oleh pajar (2008), Bambang Triatmojo (2007) dan Dwi Inneke Kartikawati (2006) bahwa motivasi kerja berpengaruh terhadap produktivitas karyawan. Dengan demikian motivasi kerja sangat penting dalam peningkatan produktivitas karyawan karena dengan motivasi pribadi diharapkan selalu meningkatkan tingkat produksi dari pekerjaan yang dikerjakan.

Pada Variabel Pengalaman kerja, nilai t hitung untuk variabel Pengalaman kerja adalah 2.062, sedangkan nilai $t$ tabelnya adalah sebesar $1.750(\mathrm{df}=50-4-1=45)$. Selain itu, nilai signifikansinya didapat 0,040 . Sehingga dapat disimpulkan bahwa secara parsial pengalaman kerja berpengaruh terhadap produktivitas karyawan. Hal ini didukung dengan penelitian terdahulu yang dilakukan oleh pajar (2008) bahwa pengalaman kerja berpengaruh terhadap produktivitas karyawan. Dengan demikian pentingnya pengalaman kerja dalam peningkatan produktivitas dari setiap karyawan, karena semakin banyak pengalaman tentunya diharapkan selalu meningkat dalam kegiatan produksi.

Pada Variabel Usia Karyawan, nilai $\mathrm{t}$ hitung untuk variabel Usia Karyawan adalah 1.757, sedangkan nilai $\mathrm{t}$ tabelnya adalah sebesar $1.750(\mathrm{df}=50-4-1=45)$. Selain itu, nilai signifikansinya didapat 0,047 . Sehingga dapat disimpulkan bahwa secara parsial usia karyawan berpengaruh terhadap produktivitas karyawan. Hal ini didukung dengan penelitian terdahulu yang dilakukan oleh pajar (2008) dan syaiful Rohmat (2007) bahwa usia karyawan berpengaruh terhadap produktivitas karyawan. Jaminan ukuran usia sangat menentukan jumlah hasil produksi,tentunya dengan asumsi apabila usianya tidak muda lagi produktivitas akan lebih lambat atau kecil daripada usia yang masih dibawahnya. Pentingnya dalam manajemen bagian Sumber daya manusia dalam melakukan pembatasan usia kerja dari perusahaan tersebut.

\section{KESIMPULAN DAN SARAN}

\section{Kesimpulan}

Dari hasil penelitian dan pembahasan pada uraian sebelumnya, dapat ditarik simpulan sebagai berikut: pertama, secara parsial atau individu usia kerja, motivasi kerja dan pengalaman kerja berpengaruh positif dan signifikan terhadap produktivitas karyawan, sedangkan tingkat pendidikan tidak berpengaruh terhadap produktivitas karyawan CV Granada secara signifikan. Kedua, secara bersama-sama tingkat pendidikan, usia kerja , motivasi kerja dan pengalaman kerja berpengaruh terhadap produktivitas karyawan CV Granada. Dan ketiga, tingkat pengaruh indikator faktor-faktor yang mempengaruhi produktivitas karyawan diperoleh $76.1 \%$ menjelaskan bahwa naik turunnya produktivitas karyawan secara bersama-sama dipengaruhi tingkat pendidikan, usia kerja, motivasi kerja, dan pengalaman kerja. Sedangkan sisanya sebesar $23.9 \%$ dipengaruhi oleh variabel lain yang tidak diteliti.

\section{Saran}

Adapun saran yang bisa disampaikan atas hasil penelitian ini adalah: pertama, faktor yang perlu dipertimbangkan untuk ke depan terutama oleh pihak perusahaan adalah tentang substansi dari motivasi kerja, usia kerja maupun pengalaman kerja. Dengan demikian diharapkan perusahaan nantinya akan menjadikan karyawan atau tenaga kerja yang handal dan mampu memproduksi secara optimal. Kedua, untuk bisa memproduksi atau menghasilkan barang yang maksimal dan optimal, maka perusahaan harus mencapai produktivitas perusahaan yang tinggi 
melalui penyeleksian tenaga kerja yang handal di samping meningkatkan kemampuan tenaga kerja dengan berbagai pelatihan diharapkan mampu mempunyai pengalaman. Dan yang ketiga, untuk selanjutnya diharapkan dapat mengembangkan penelitian ini dengan menilai variabel penelitian lainya yang dapat digunakan untuk menilai peningkatan produktivitas karyawan selain variabel dari penelitian diatas.

\section{DAFTAR PUSTAKA}

Anoraga, Pandji, 2005, Manajemen Bisnis, Cetakan Ketiga, Jakarta: Rineka Cipta

Bambang Triatmojo. 2009. "Pengaruh Motivasi, Kedisiplinan dan Pengalaman Kerja Karyawan Koperasi Unit Desa Kedalisono Tawangharjo Grobogan”. Skripsi: STIE- AUB

Cahyono, Yuli Tri., Indira M., Lestiyana. (2007). Pengaruh Perencanaan dan Pengawasan Terhadap Produktivitas Kerja Karyawan Pada Perusahaan Manufaktur Di Surakarta. Jurnal Akutansi dan Keuangan, Vol. 222-223.

Depdiknas. (2013). Kamus Besar Bahasa Indonesia, Edisi Ketiga. Jakarta: Balai Pustaka.

Dwi Ineke Kartikawati. (2006). "Hubungan antara Sistem Pengupahan dan Motivasi Kerja dengan Produktivitas Kerja karyawan pada Industri Wingko di Kulon Progo". Skripsi. Universitas Negeri Yogyakarta.

Elaine B. Johnson. 2007. Contextual Teaching and Learning. MLC Bandung

Gomes, F. C. 2005. Manajemen Sumberdaya Manusia. Andi Offset. Yogyakarta.

. Organisasi dan Motivasi. Bina Pustaka. Jakarta.
Handoko, T. Hani. 2003. Manajemen, Cetakan Kedelapanbelas, BPFE Yogyakarta, Yogyakarta.

Handoyo, Rossanto Dwi,2006 Materi Pokok Ekonomi Sumber Daya Manusia, Cetakan 1, Jakarta: Universitas Terbuka. Hadari Nawawi. 2001. Manajemen Sumber Daya Manusia. Bumi Aksara. Jakarta

Husein Umar. 2003.Riset SDM Dalam Organisasi. Edisi Revisi. Cetakan kelima. PT. Gramedia Pustaka Utama. Jakarta

Imam, Ghozali. 2009. Aplikasi Multivariate dengan Program SPSS, Semarang: Badan Penerbit Universitas Diponegoro.

J. Simanjuntak, Payaman, dalam pajar 2007 Pengantar Ekonomi Sumber Daya Manusia, Lembaga Penerbit Fakultas Ekonomi Universitas Indonesia, Jakarta

Kusnendi dkk. 2003 Ekonomi Sumber Daya Manusia dan Alam. Jakarta: Universitas Terbuka.

Ngalim Purwanto 2007 Psikologi Pendidikan ,Jakarta : PT Remaja Rosdakarya

Malayu S.P, Hasibuan. 2006, Manajemen Sumber Daya Manusia. Bumi Aksar. Jakarta.

Marihot T. E Hariandja. 2005. Manajemen Sumber Daya Manusia. PT. Gramedia Widiasarana Indonesia. Jakarta.

Pajar, 2008. Analisis factor yang mempengaruhi produktivitas kerja karyawan bagian keperawatan pada Rumah Sakit PKU Muhammadiyah Surakarta.Skripsi :UMS Surakarta

Priyanto, Didik, (2006). "Analisis Tingkat Pendidikan dan Pengalaman Kerja Terhadap Produktivitas Kerja Karyawan Bagian Keperawatan pada 
Saiful Rohmat 2007, Pengaruh Produktivitas Tenaga Kerja Terhadap Kinerja Perusahaan : Jurnal Ekonomi

Sondang P Siagian. 2006. Manajemen Sumber Daya Manusia. PT. Bumi Aksara. Jakarta.

Susilo Martoyo ,2004 : Manajemen Sumber Daya Manusia, alfabeta : Bandung
Van Den Ban. A.W. dan H.S Hawkins., 1999. Penyuluhan Pertanian. Kanisius. Yogyakarta.

Winardi, 2000, Manajer dan Manajemen. Bandung: Citra Aditya Bakti.

Yuniarsih, Tjujtu dan Suwatno. 2009; Manajemen Sumber Daya Manusia, Alfabeta. Bandung 